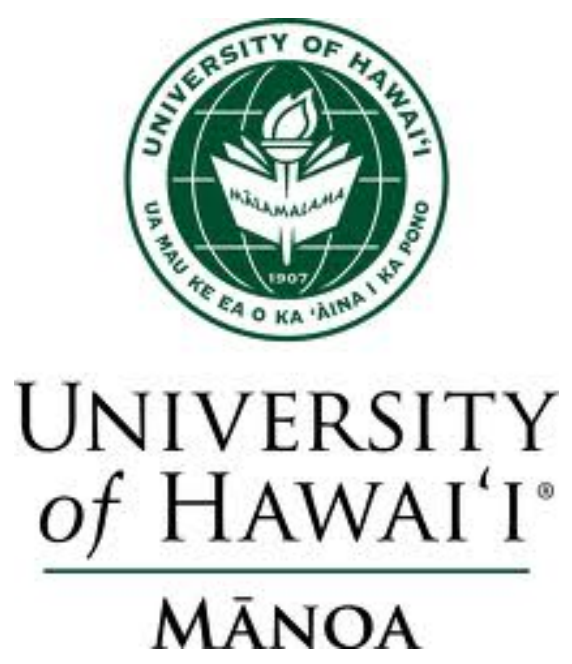

University of Hawai 'i at Mānoa Department of Economics Working Paper Series

Saunders Hall 542, 2424 Maile Way, Honolulu, HI 96822

Phone: (808) $956-8496$ www.economics.hawaii.edu

Working Paper No. 12-19

How Have Catch Shares Been Allocated?

By

John Lynham

August 2012 


\title{
How Have Catch Shares Been Allocated?
}

\author{
John Lynham*†
}

May 2, 2012

\begin{abstract}
A unique database was created that describes the methods used to allocate shares in nearly every major catch share fishery in the world. The main approaches used to allocate catch shares include: (i) auctions, (ii) equal allocation, (iii) historical catch records and (iv) vessel- or gear-based rules. 54\% of the major catch share fisheries in the world allocated the Total Allowable Catch (TAC) on the basis of historical catch records, 3\% used auctions, and $6 \%$ used equal sharing rules. $37 \%$ used a combination of methods, including vessel-based rules. $91 \%$ of the fisheries in the database allocated some fraction of the TAC on the basis of historical catch. These results confirm the widely-held belief that nearly all catch share programs have "grandfathered" private access to fishery resources. This publicly available database should be a useful reference tool for policymakers, academics, and others interested in catch shares management in Hawai'i and across the globe.
\end{abstract}

Keywords: catch shares, ITQ, allocation, auction

*Department of Economics, Saunders Hall 542, University of Hawai'i at Mānoa, 2424 Maile Way, Honolulu, Hawai'i 96822

${ }^{\dagger}$ To whom correspondence should be addressed. Email: lynham@hawaii.edu. Phone: (808)-956-8280. Fax: (808)-956-4347 


\section{Introduction}

The debate over catch shares management has intensified recently, in both academic and policy circles. ${ }^{1}$ Most commentators would agree that catch shares improve the aggregate economic performance of a fishery, especially in terms of measures such as total profit generated. However, in terms of other (often more finescale) metrics, such as total jobs, crew remuneration, number of active vessels or processor profit, there is little agreement over the impact of catch share systems: both in terms of the direction of the impact and its desirability. For example, [1] study the introduction of catch shares to the Bering Sea/Aleutian Island crab fisheries and find that the number of individuals employed in the fishery declines but that the total crew-hours dedicated to fishing activities remains roughly constant.

In terms of ecological impacts, the evidence is also conflicting. [10] find that catch share fisheries are less likely to be collapsed compared to all other fisheries grouped together. [16] corroborate the findings in [10] using similar data but a different empirical strategy. [6] finds that catch shares have largely positive effects on target species, but mixed or unknown effects on non-target fisheries and the overall ecosystem. [9] finds that biomass increased in 60 per cent of a sample of catch share fisheries but continued to decline in the remaining 40 per cent. [13] evaluate 15 North American catch share fisheries: for a variety of ecological indicators, no change in means was observed after switching to catch shares (except for a decline in the discard rate). There was, however, a significant reduction in the variability of all ecological indicators leading to the conclusion that the primary effect of catch shares was greater consistency over time. [21] and [14] find similar results using expanded databases of catch share fisheries.

One of the positive elements to emerge from the often acrimonious debate over catch shares is the recognition that the design of a catch share program is critically important. One of the key design features in any catch share program is deciding how to allocate the shares. Until recently, the role of allocation in cap-and-trade programs generally and catch shares specifically has been largely ignored by economists. The Coase theorem predicts that the aggregate outcome of a cap-and-trade system should be independent of the initial allocation, which may explain why "allocation is generally considered by economists as merely a distributional, political issue" [8, p. 159]. But recent theoretical and empirical research has suggested that the allocation process may play a pivotal role in the actual performance of a cap-and-trade policy $[30,22,3]$. Since allocation often determines who are the winners and losers under a new catch share program, perceptions of how catch shares will be allocated will strongly influence which parties support or block the transition $[31,17,28]$.

\footnotetext{
${ }^{1}$ For some of the issues in the academic debate, see [7], [20] and [11]. In the policy arena, see "Catch-and-Trade Catastrophes: Failures in Fishery Quota Programs" available at http://www.foodandwaterwatch.org for one view and "Assessing the Potential for LAPPs in U.S. Fisheries" available at http://www.edf.org for another.
} 
The aim of this paper is to simply present some empirical data on how catch shares have been allocated, where and when this has happened and, why a particular approach was adopted. In some cases, attention is drawn to where particular outcomes may have been due to the allocation method chosen. In order to do this, a unique database on catch share allocation mechanisms was created. Section 2 explains how the database was constructed and presents some general summary statistics. The main methods used to allocate catch shares include: (i) auctions, (ii) equal allocation (iii) historical catch records and (iv) vessel- or gearbased rules. Each method is discussed in turn in Section 3 and the entire database is presented in an online appendix. The paper concludes with a discussion of how the lessons learnt from the global experience with allocation might apply to the two Hawai' i-based fisheries sometimes considered for catch shares management: the longline pelagic fishery and the nearshore deep-water bottomfish fishery.

\section{Material and methods}

The starting point for constructing the database was the set of catch share fisheries from around the world used in [10]. This means that the database is restricted to large fisheries using ITQs (Individual Transferable Quotas) as as a form of catch shares management and it only includes catch share programs adopted by 2004 (there are currently 158 fisheries in the database). The allocation method used when each fishery initially switched to catch shares management was determined and linked to each fishery. A variety of sources were used to make this determination but most sources were either academic articles or government reports. The main methods used to allocate catch shares include: (i) auctions, (ii) equal allocation (iii) historical catch records and (iv) vessel- or gear-based rules. Due to difficulties with verification, a category for allocations to indigenous peoples was not created but this has been a feature of a number of catch share programs and will be discussed later. Based on estimates obtained using the database, $54 \%$ of the major catch share fisheries in the world allocated all or nearly all shares on the basis of historical catch, 37\% used a combination of methods, $6 \%$ used equal sharing rules and $3 \%$ used auctions (see Figure 1).

$91 \%$ of the fisheries in the database allocated some fraction of the TAC on the basis of historical catch, $30 \%$ allocated some fraction using auctions, $9 \%$ used vessel- or gear-based rules, and $7 \%$ used equal sharing rules (see Figure 2). ${ }^{2}$ This provides support for the contention that "Catch shares - portions of a fixed total allowable catch (TAC) - are given away free (gifted) to members of a specific fishery based on certified catch history over a politically determined time period" [7, p. 281] but there are clearly many exceptions to this rule. Grandfathering is not the only way to allocate shares but, to date, this has been the most popular approach. The database should hopefully prove to be a useful reference tool for policymakers interested in

\footnotetext{
${ }^{2}$ These percentages do not sum to $100 \%$ since many fisheries used a combination of different methods to allocate the TAC.
} 
Figure 1: Proportion of Catch Share Allocation Methods in the Database

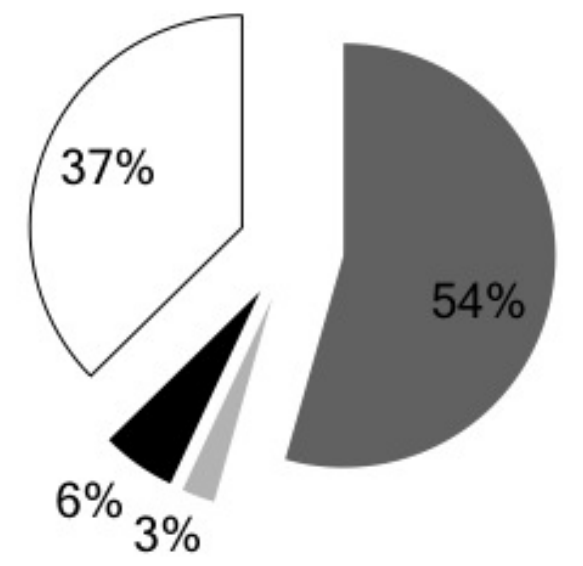

- Historical Catch Auction

- Equal $\square$ Combination

Notes: Pie chart summarizing the database of catch share allocation methods. $54 \%$ of the major catch share fisheries in the world allocated shares on the basis of historical catch, $37 \%$ used a combination of methods, $6 \%$ used equal sharing rules and $3 \%$ used auctions. 
Figure 2: Frequency of Catch Share Allocation Methods in the Database

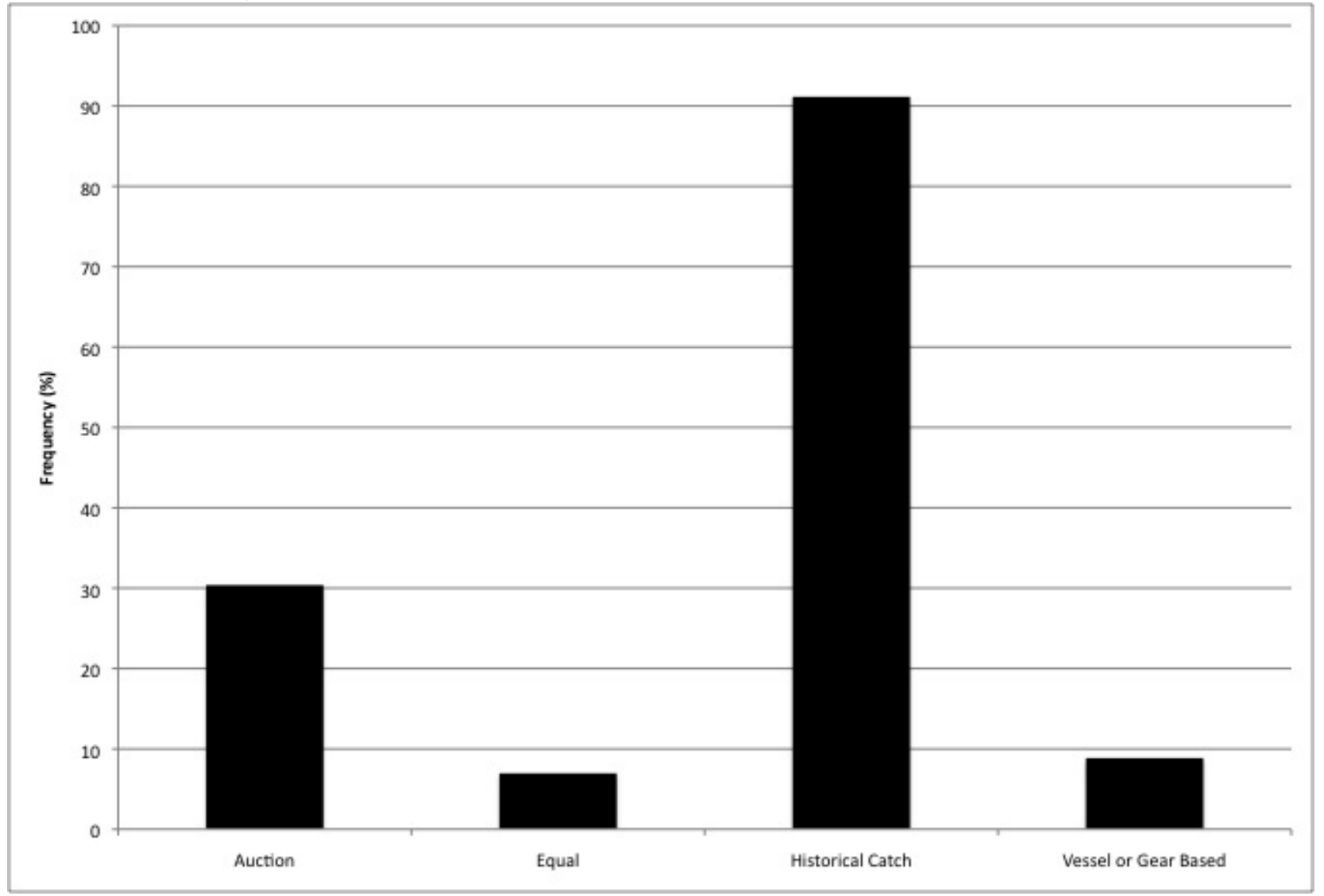

Notes: Bar chart summarizing the frequency with which an allocation method appears in the database. $91 \%$ of the fisheries in the database allocated some fraction of the TAC on the basis of historical catch, 30\% used auctions, $9 \%$ used vessel- or gear-based rules, and $7 \%$ used equal sharing rules

the types of allocation systems used to assign catch shares. 


\section{Results}

\subsection{Auctions}

Table 1: Summary Statistics for Auction Allocation Fisheries

\begin{tabular}{lcccc} 
Country & No. of Fisheries & Subsequently Revised & Earliest Adoption & Most Recent Adoption \\
\hline Estonia & 9 & 9 & 2001 & 2001 \\
Chile & 4 & 0 & 1992 & 1997 \\
New Zealand & 25 & 6 & 1996 & 2004 \\
Russian Federation & 10 & 10 & 2001 & 2001 \\
\hline Combined & 48 & 25 & 1992 & 2004 \\
\hline
\end{tabular}

Notes: Summary of fisheries that have used auctions to allocate all or part of the TAC. Column 2 lists the number of fisheries by country, Column 3 lists the number that subsequently revised the initial allocation method, Column 4 lists the year the first fishery in each country adopted auctions to allocate shares and Column 5 lists the most recent use of this mechanism.

Most economists would advocate that the best method for allocating a publicly held resource to private individuals is through an auction. This position has been strongly advocated by professional economists for resources such as air, oil, water and grazing lands. ${ }^{3}$ The arguments in favor of auctions in a fisheries context include compensating the general public for allowing private individuals to profit from exclusive access to a public resource; allowing all interested parties the opportunity to enter without favoring incumbents; and encouraging competition and efficiency, especially if the transactions costs associated with trading permits are high or there are tight restrictions on trading permits. Finally, the revenue from catch share auctions can be used for a number of government programs that would be of benefit to all in the fishery and also the general public such as stronger enforcement and record keeping or providing incentives to reduce highgrading, by-catch and habitat damage [19]. [19] further argues that both the fishery and the environment can be significantly better off with a mixture of auctions and historical catch allocations.

Table 1 summarizes the data on where and when auctions have been used to allocate catch shares. To date, only a handful of catch share fisheries have used auctions to allocate initial shares, mainly in Chile, Estonia and the Russian Federation. In Chile, auctions were used to allocate catch shares in the squat lobster (Pleuroncodes monodon) and black cod (Dissostichus eleginoides) fisheries in 1992, and the yellow prawn (Cervimunida johni) and orange roughy (Hoplostethus atlanticus) fisheries in 1997. ${ }^{4}$ The Chilean method of auctioning quota can be loosely summarized as follows. Initially, 90 or $100 \%$ of the TAC is allocated through an auction and the remaining 10 or $0 \%$ is allocated based on historical catch. The corresponding catch shares last ten years but are reduced by $10 \%$ each year. Consequently, $10 \%$ of the total TAC (which has been made

\footnotetext{
${ }^{3}$ For example, see the Economist Statement on Cap-and-Trade Auctions at www.cleanenergy.org.

${ }^{4}$ The information on catch share allocation in Chile is obtained from [24].
} 
available by reducing every ITQ by 10\%) is re-auctioned annually. The decision about whether to auction 90 or $100 \%$ of the TAC is based on whether a fishery is in the "under recovery" or "infant development" stage and whether there are established fishermen in the fishery.

Estonia switched to a form of catch shares management in $2001 .^{5}$ Since all of the fishing enterprises in Estonia were relatively new at the time, it was felt that there was insufficient history to give fishermen a real "historical right" for the exclusive use of fish stocks. Catch shares were allocated in part by auction and in part on the basis of historical participation (eventually, $10 \%$ by auction and $90 \%$ by catch history). In a similar fashion to Chile, all catch shares depreciate by $10 \%$ each year (except in a geometric fashion) and the recovered quota is re-auctioned every year by the Estonian government. From 2001 to 2003, fish quotas in the Russian Far East were allocated by auction using a very similar system to the Estonian one [4]. The purpose of the auctions was to divert some of the resource rent to the state budget and to increase the transparency of the quota allocation mechanism.

Auctions have also been used in New Zealand. Prior to 1996, most catch shares in New Zealand were allocated purely on the basis of historical catch. However, starting in 1996, the option to auction quota for new catch share species has been available and has sometimes been executed. Quota is first allocated to Māori (20\% of any new species) and then allocated to fishing operations on the basis of average historical catch. If there is any quota remaining after this allocation, then the New Zealand government has the option to auction this unallocated catch [2]. As a result, a small but not insignificant amount of quota for some species has been auctioned.

\subsubsection{Outcomes}

The auction in Estonia generated significant revenue for the Estonian government. In terms of changes in the fleet structure, bigger vessels are more profitable in most Estonian fisheries so, not surprisingly, there was an increase in the amount of fishing rights held by bigger vessels after the introduction of the quota auction, since they were willing to pay more for the same quota relative to smaller vessels. In terms of the amount of quota bought by any one enterprise, the largest amount bought was $38.5 \%$ and the smallest amount was $0.137 \%$ (of the $10 \%$ of the TAC that was auctioned). It is generally accepted that the auction led to greater concentration in the industry. However, it did not lead to a concentration of quota away from remote areas to more central areas. In the Russian auctions, a lot less of the TAC ended up being sold than was originally intended. The auctions provided substantial income for the Russian government but they led to a decline in industry profits, greater indebtedness of the industry and may have encouraged greater illegal fishing [4].

It is interesting to note that the re-auctioning system in Estonia has subsequently been abandoned

\footnotetext{
${ }^{5}$ The information on catch share allocation in Estonia is obtained from [33].
} 
because of pressure from the fishing industry. In 2004, the auction system was also abandoned in Russia. New Zealand has also run in to difficulties with the auctioning of quota. Auctions were held for some of the quota for post-1996 species in 2001, but the government decided to not distribute this quota after concerns were raised about the inequity of the process [2]. It is also interesting to note that although the catch share systems based on auctions in Chile appear to be working well, auctions have not been used in subsequent catch share allocations. Based on the experiences of Chile, Estonia, New Zealand and the Russian Federation, it appears that some of the most important design factors to consider when crafting an auction allocation system include: (i) the type of auction used (English, sealed-bid, etc.), (ii) the size of the shares sold at the auction, (iii) consolidation limits, and (iv) whether bids are paid up front or when fish are landed. These factors will have a critical influence on who can participate in the auction and the degree of concentration among share holders. It also appears that the effect of auctions on industry profits and the lobbying strength of the fishing industry play a key role in the success of auction allocation mechanisms.

\subsection{Equal allocation}

Table 2: Summary Statistics for Equal Allocation Fisheries

\begin{tabular}{lcccc} 
Country & No. of Fisheries & Subsequently Revised & Earliest Adoption & Most Recent Adoption \\
\hline Australia & 3 & 0 & 1985 & 1994 \\
Canada & 4 & 0 & 1989 & 1996 \\
Iceland & 3 & 0 & 1975 & 1988 \\
USA & 1 & 0 & 1992 & 1992 \\
\hline Combined & 11 & 0 & 1975 & 1996 \\
\hline
\end{tabular}

Notes: Summary of fisheries that have used equal shares to allocate all or part of the TAC. Column 2 lists the number of fisheries by country, Column 3 lists the number that subsequently revised the initial allocation method, Column 4 lists the year the first fishery in each country adopted equal shares to allocate shares and Column 5 lists the most recent use of this mechanism.

Equal allocation of catch shares is, like auctions, a mechanism that is often advocated (particularly by parties outside of the fishery) but fiercely resisted (usually by parties inside the fishery). The standard argument in favor of an equal allocation mechanism is that it is, by definition, "equitable". A secondary argument is that equal allocation avoids contentious decisions about how to use historical catch records to assign shares. However, equal allocation mechanisms are often based on historical catch records since these are used to determine who has participated in the fishery and is therefore eligible for an equal share of the TAC. This can create a whole new set of disagreements but it is usually easier to determine who has participated in a fishery as opposed to the degree of participation. 
Although the standard practice in Iceland has been to allocate shares on the basis of historical catch, there are at least three fisheries in Iceland that initially used an equal allocation mechanism to assign part or all of the TAC. ${ }^{6}$ For the herring (Clupea harengus) and inshore shrimp (Pandalus borealis) fisheries that switched to ITQs in 1975 and 1984, respectively, catch shares were allocated equally to all eligible vessels. The same methodology was used for the capelin (Mallotus villosus) fishery in 1980, except that a third of the TAC shares were initially allocated on the basis of vessel hold-capacity (see Section 3.4 for a discussion of this type of approach).

Equal allocation systems have also been used to assign catch shares in Canada and Australia. ${ }^{7}$ When Canada's geoduck (Panopea generosa) fishery switched to catch shares in 1989, each license was granted an equal share of the TAC (this turned out to be $1.8 \%$ for each license). This allocation method was again used in 1995/6 when the Canadian government approved catch shares for the green sea urchin (Strongylocentrotus droebachiensis), red sea urchin (Strongylocentrotus franciscanus) and sea cucumber (Parastichopus californicus) fisheries on the Pacific Coast. The government directed that $2 \%$ of the TAC in each fishery would be reserved for First Nations while the remaining $98 \%$ would be split equally among the licenses in the commercial fishery. For the green sea urchin fishery this amounted to each license receiving $2 \%$ of the commercial TAC, $0.91 \%$ for red sea urchin, and $1.18 \%$ for sea cucumber. In the Western Australia abalone fishery, equal allocation methods have also been used. Switching to catch shares was a gradual process starting in 1985, but was formally adopted in 1999. Historical catches were not used as a basis for allocating catch shares because the fishery participants saw equal shares as a more equitable and acceptable allocation method. Likewise, in the Southern Australia abalone (Haliotis laevigata and Haliotis rubra) and pilchard (Sardinops neopilchardis) fisheries, allocation was done on an equal basis among all existing licence-holders.

There's only one example of an equal allocation approach in the US and that's the wreckfish (Polyprion americanus) fishery in the south Atlantic, which switched to catch shares in 1992. This fishery used a mix of historical catch and equal shares to make the initial allocation. $50 \%$ of the catch shares were allocated in direct proportion to catch recorded from 1987 to 1990. The remaining 50\% was divided equally among all eligible participants [15].

\subsubsection{Outcomes}

For most of the fisheries mentioned above, the majority of the participants agreed to equal sharing of the TAC as the best way to allocate quota and so there was no subsequent appeals process to deal with licenseholders who disagreed with the allocation formula. A number of these fisheries started out as catch share

\footnotetext{
${ }^{6}$ The information on catch share allocation in Iceland is obtained from [25]. It should be noted that one of these allocations (Clupea harengus) occurred over 35 years ago and may not be relevant to many modern catch share programs.

${ }^{7}$ The information on geoduck catch share allocation in Canada is obtained from [29].
} 
fisheries without trading and this was subsequently changed but, as for a government-mandated reallocation of quota, there are no records of this ever occurring in a catch share fishery that allocated shares equally (for the sample of fisheries in the database). However, the US wreckfish fishery did set an individual cap of $10 \%$ of the TAC because of concerns over the fairness of the allocation formula used [15]. In the Icelandic fisheries, it appears that equal allocation was not particularly controversial because boats were all roughly the same size with equal catch history. The most critical decision in any equal allocation system is deciding which vessels are "eligible" to receive an allocation. For example, in the Icelandic herring allocation in 1975, all vessels with a history of catching herring from the late 1960s and still in operation were eligible for a catch share. Beyond the eligibility issue, the design of the allocation is quite straightforward compared to other options. In many ways, equal allocation mechanisms have been de facto historical catch allocations since they have mainly been adopted in fisheries where most participants had very similar catch histories.

\subsection{Historical catch}

Table 3: Summary Statistics for Historical Catch Allocation Fisheries

\begin{tabular}{lcccc} 
Country & No. of Fisheries & Subsequently Revised & Earliest Adoption & Most Recent Adoption \\
\hline Australia & 21 & 0 & 1983 & 2000 \\
Canada & 19 & 0 & 1989 & 1997 \\
Estonia & 9 & 9 & 2001 & 2001 \\
Iceland & 23 & 7 & 1975 & 2001 \\
Netherlands & 5 & 2 & 1976 & 1996 \\
New Zealand & 61 & 36 & 1986 & 2004 \\
Russian Federation & 10 & 10 & 2001 & 2001 \\
USA & 4 & 0 & 1990 & 1995 \\
USA and Canada & 2 & 0 & 1990 & 1991 \\
\hline Combined & 154 & 64 & 1975 & 2004 \\
\hline
\end{tabular}

Notes: Summary of fisheries that have used historical catch to allocate all or part of the TAC. Column 2 lists the number of fisheries by country, Column 3 lists the number that subsequently revised the initial allocation method, Column 4 lists the year the first fishery in each country used historical catch to allocate shares and Column 5 lists the most recent use of this mechanism.

The most common method used globally to allocate quota when a fishery initially switches to an ITQ system is to grandfather quota on the basis of historical catch records. $91 \%$ of the fisheries in the global database used this approach to allocate some portion of the TAC. The arguments in favor of using historical catch records include using the free allocation of quota to existing fishermen as a "carrot" to get agreement on a new catch share system as well as recognizing the investment and effort that existing fishermen have put into a fishery. A further argument has been made recently by [3] that grandfathering increases dynamic efficiency compared to the alternatives. Some of the arguments against historical allocation include many 
of the arguments in favor of auctions as well as the concern that, if fishermen anticipate a catch allocation based on historical catch, this may induce a race for catch history.

The two global leaders in catch share adoption, New Zealand and Iceland, have generally used historical catch as the metric for allocating shares. Nearly all of the ITQ systems in New Zealand were established this way. New Zealand's catch share system was formally launched on the 1st October 1986 for 26 different species, comprising 156 different stocks. The guiding principle for allocating quota was to use "commitment" to the fishery. For the near-shore fisheries, the metric for estimating commitment was catch history over a three-year time horizon (1982-84). The catch history assessment involved an initial estimate by the Ministry of Agriculture and Fisheries for every relevant party for the three qualifying years; this information was then reported to each fisherman in 1985. Fishermen were then asked to select two of these three years to establish their entitlement. Each fisherman was then allocated the average of these two years as his or her "provisional" ITQ.

Because of a serious need to reduce catch levels in some of these fisheries, fishermen were also notified how their provisional ITQ would be reduced if there was a uniform reduction in all ITQs. However, instead of a unilateral reduction of ITQ in a fishery, the government set out to reduce the total amount of ITQ through a buy-back scheme. This was initially done through an auction but the bids by fishermen were too high to achieve the necessary reductions within budget. At bid prices, the government would have achieved only $60 \%$ of the required reductions. About $25 \%$ of the required cuts were obtained using auctions. The government then set fixed prices for quota and coupled this with the threat of unilateral reductions if the necessary reductions were not achieved. A strong response was received, but all TACs were not yet satisfied so any remaining reductions were achieved with across-the-board cuts. As [26] point out, the buy-backs cost the government more than the real catch reductions achieved were worth. For deep-water species, the overall process was similar to the near-shore fisheries but involved a combination of historical catch with the amount of investment a firm had placed in processing, employment and capital. There was no buy-back of quota in this instance.

In the demersal (for example, Gadus morhua and Melanogrammus aeglefinus), lobster (Nephrops norvegicus), scallop (Chlamys islandica) and deep-sea shrimp (Pandalus borealis) fisheries in Iceland, the catch share allocations were based on the vessel's historical catch record during certain base years [5]. In the demersal fisheries this usually equalled the vessel's average share in the total catch during the three years prior to the introduction of catch shares in 1984. There were exceptions to this rule, for example, if a vessel had not been operating normally during 1981-1983 then the calculated share was adjusted upwards. Nowadays, the accepted practice in Iceland is to issue shares in new catch share fisheries on the basis of the three most recent years of historical catch. 
Allocations on the basis of catch history have also occurred in Australia. ${ }^{8}$ The allocation of the TAC into catch shares for the Southern Australia rock lobster (Jasus edwardsii) fishery generated considerable debate and a number of allocation models were discussed with existing licence-holders. Eventually, a process known as the "adjusted preferred method" was selected. Fishermen were allowed to choose their preferred allocation method. The choices were limited to a number of set options such as on the basis of average catch over the past 3 years, 2 years, current pot entitlement, etc. After each fishermen chose an allocation method, his/her catch share was then computed using the chosen method. The catch shares were then summed to give a total catch and the individual shares were then uniformly scaled back to match the desired TAC. The resultant share was the individual's assigned catch share. Historical allocation has also been used in a number of other countries, including Canada, Estonia, the Netherlands, Russia, the US and Canada. Every single US-based fishery in the database has used historical catch to allocate some portion of the TAC.

\subsubsection{Outcomes}

Assigning catch shares on the basis of historical catch has been a smooth process in some cases and highly contentious in others. In New Zealand, there was a lengthy appeals process following the initial allocation in the 1980s. The introduction of catch shares in New Zealand assumed that there would be no effect on Māori fishing claims, which were established in the Treaty of Waitangi. But subsequent claims and reports by the Waitangi Tribunal disputed this, leading to a significant and lengthy settlement process between Māori and the Crown government of New Zealand. A new allocation process was introduced in the 1996 Fisheries Act.

In Iceland's demersal fishery, several vessel-owners complained about their initial quota shares in 1984 and subsequent changes were made. Interestingly, from 1985 to 1987 it was possible to modify a vessel's catch share by opting for effort restrictions instead of vessel quotas and then demonstrate high catches during this period. In Iceland, a large part of the general public now questions the fairness of the initial allocation of catches [25]. [25] argue that perhaps it is not so much the fairness of the allocation itself (most people realize that fishermen should be the ones who actually work in the fishery) but the allocation of the shares without fees or rentals paid to the Icelandic government. Villages and towns from which quotas have been transferred are typically critical of the initial allocation process and argue that their community should have received its own spatially specific quota. Within the industry, a subset of fishing labor remains critical of the allocation process, especially crew members who have to contribute to the cost of quota purchases by vessel owners [25].

In the Netherlands, catch shares were initially allocated in 1976 on the basis of historical catch over the

\footnotetext{
${ }^{8}$ The information on catch share allocation in the Southern Australia rock lobster fishery is obtained from [23].
} 
period 1972-74..$^{9}$ However, in 1977, due to widespread dissatisfaction, the allocation rule was altered to be based partly on historical catch and partly on the engine power of the vessel. This vessel-based allocation rule is explained in more detail in Section 3.4 but one of the contributing factors to the dissatisfaction with the historical catch allocation was the decision to assign catch history to a vessel instead of an individual. In the British Columbia groundfish trawl fishery, which switched to catch shares in 1997, vessel owners who had entered the fishery in the late 1980s and early 1990s were obviously unhappy with the decision to use catches from 1986 to 1989 to determine catch records. Based on global experiences, it appears that some of the most important design factors to consider when crafting an allocation system based on historical catch include: (i) addressing individuals or groups who may not have catch history records but have historically caught fish in the fishery, (ii) deciding the time horizon used to calculate historical records, (iii) deciding whether averages or "best of" metrics will be used, and (iv) who to assign the catch history to, i.e. the vessel, the captain, the owner, the crew, the processor?

\subsection{Vessel- or gear-based allocation}

Table 4: Summary Statistics for Vessel/Gear Based Allocation Fisheries

\begin{tabular}{lcccc} 
Country & No. of Fisheries & Subsequently Revised & Earliest Adoption & Most Recent Adoption \\
\hline Canada & 10 & 0 & 1997 & 1997 \\
Iceland & 1 & 0 & 1980 & 1980 \\
Netherlands & 3 & 2 & 1976 & 1994 \\
\hline Combined & 14 & 2 & 1976 & 1997 \\
\hline \hline
\end{tabular}

Notes: Summary of fisheries that have used vessel- or gear-based rules to allocate all or part of the TAC. Column 2 lists the number of fisheries by country, Column 3 lists the number that subsequently revised the initial allocation method, Column 4 lists the year the first fishery in each country used vessel- or gear-based rules to allocate shares and Column 5 lists the most recent use of this mechanism.

Vessel or gear based allocation methods are similar in spirit to equal allocation approaches but try to account for the fact that different vessel types may have caught more fish in the past, anticipate catching more in the future or represent a greater "commitment" to the fishery. In this sense, they can be considered a hybridization of equal and historical catch allocations. The arguments in their favor include avoiding contentious debates over deciding catch history and having a more "equitable" allocation of catch that still recognizes differences within the fleet. Vessel based allocations have been considerably rare to date and occur in only $9 \%$ of the fisheries in the database of catch share allocations.

\footnotetext{
${ }^{9}$ The information on catch share allocation in the Netherlands is obtained from [12], [27] and [5]. Again, some of these older case studies may not be relevant to modern allocation decisions.
} 
The plaice and sole fisheries in the Netherlands switched to a form of catch shares management in 1976. Holland's national quota was allocated as individual quotas to vessels on the basis of historical catch shares and vessel capacity measured in terms of engine power. As mentioned in Section 3.3.1, the initial shares were allocated in 1976 on the basis of historical catch over the period 1972-74. However, in 1977, due to widespread dissatisfaction, the allocation rule was altered to be based $50 \%$ on historical catch and $50 \%$ on the engine power of the vessel. Similar allocation rules applied to the cod fishery, which switched to catch shares in 1994.

One of the reasons for the Netherlands adopting a vessel-based system was due to catch shares being assigned to a particular vessel. Under this type of system, new vessels owned by existing fishermen would have no catch history. Therefore, the relationship between engine power and the landings of sole and plaice in the reference years was derived from fisheries data. Some owners who had changed their vessels complained that one should account for their fishing results being better than the average for their engine power group during the reference period. This was one of the reasons for settling on the $50 / 50$ rule.

When the capelin fishery in Iceland switched to ITQs in 1980, a third of the shares were allocated on the basis of vessel capacity, in particular the size of the hold. As outlined in [32], the British Columbia groundfish fishery allocated catch shares using a combination of historical catch and vessel-based rules. $70 \%$ of each licenced vessel's initial allocation was based on 1986 to 1989 catch history (the switch did not occur until 1997) and $30 \%$ was based on vessel length. This allocation method accounted for $80 \%$ of the TAC, the remaining $20 \%$ is allocated by the government to programs designed to aid regional development, attain market and employment objectives, support sustainable fishing practices, and ensure fair treatment of crew members.

\subsubsection{Outcomes}

Catch shares management in the Dutch plaice and sole fisheries got off to a rocky start due to a lack of effective control and punishment. In the initial years of the program, evidence mounted that total landings actually exceeded the TAC [27]. However, once monitoring and enforcement were improved, perception of the system among participants and the general public improved considerably. One particular problem which remains is the high cost of establishing a new business in the Dutch demersal fisheries. Because the catch share is tied to a vessel, new entrants must finance both a vessel and harvesting rights.

In the British Columbia groundfish trawl fishery, small vessels opposed the allocation formula stating that it favoured large boats and did not recognize that small boats often focused on delivering a quality product rather than large volumes [32]. Based on the experiences of Canada, Iceland and the Netherlands, some of the key design factors to consider in a vessel- or gear-based allocation include: (i) deciding which 
vessels are eligible to receive an allocation, (ii) creating a formula that links vessel size or gear type to a particular catch allocation, (iii) deciding whether the catch share is tied to the vessel, the owner or the crew and, (iv) dealing with retirement of vessels or gear from the fishery, i.e. what happens to the catch shares associated with a particular vessel?

\section{Discussion}

In terms of the link between allocation mechanisms and subsequent outcomes, it should be pointed out that there is no serious analysis in this paper. It would be extremely difficult to establish causality between an allocation mechanism and fishery outcomes using observational data. The aim of this paper is to create the first global database of catch share allocations and present some basic facts on how catch shares have been allocated in different fisheries around the world. However, there are some obvious correlations that we can draw attention to and there are some general points that could be relevant to future allocation decisions in Hawai'i and elsewhere.

In very general terms, the global experience with catch share allocation can be summarized as follows. Nearly every single fishery has used historical catch numbers to allocate some of the TAC. This is typically necessary to garner support from incumbent fishermen and to recognize financial investment in the fishery. If historical catch forms the basis of the allocation decision in the Hawai'i-based longline fishery, then most of the data necessary to do this is readily available. However, establishing historical catch records for the bottomfish fishery will be extremely difficult since a large fraction of the catch has been historically unreported.

It is interesting to note that, simply in terms of subsequent revisions, auctions have been the most contentious method, followed by historical catch. $52 \%$ of the fisheries in the database that used auctions to allocate part of the TAC subsequently revised how the TAC was initially allocated and $41 \%$ of historical catch allocations were later revised. None of the equal share allocations were ever revised after the fact. The same is true for vessel- or gear-based rules; in fact, some historical catch allocations have been revised to include vessel-based rules. Auctions appear to work only in newly developed fisheries and for species that are not migratory, suggesting that they will face serious opposition in Hawai'i.

In terms of lessons from specific allocation processes, relevant fisheries for Hawai'i include New Zealand's bigeye (Thunnus obesus) and yellowfin tuna (Thunnus albacares) fisheries as well as the Gulf of Mexico red snapper (Lutjanus campechanus) fishery in the US. Following a review of management options in 2003, the New Zealand government decided to switch its tuna fisheries to catch shares. These fisheries are relevant since a portion of the catch is caught on the high seas, much like the Hawai'i-based longline fishery. Catch 
shares management now applies to all major tuna fisheries within New Zealand waters and, where a national allocation is agreed through the relevant Regional Fisheries Management Organization, for tuna species taken by New Zealand fishers outside New Zealand waters. The allocation of catch shares in New Zealand's tuna fisheries was based on historical catch records and this proved contentious with different fishers promoting the use of different catch history years as a basis for quota allocation. Given that historical catch is fairly well documented in the Hawai'i longline fishery, and the capital-intensive nature of this fishery, historical catch records will probably play a large role in any future allocation process.

The Gulf of Mexico red snapper fishery switched to catch shares in 2007 after an unsuccessful attempt in the 1990s. This fishery is different to many other catch share fisheries in that there is a large recreational component and the catch shares are for one species in a multi-species fishery. These represent two obvious similarities with the Hawai'i bottomfish fishery. One of the major issues in both the initial and actual catch share allocation process in the Gulf of Mexico was how to accommodate the large recreational sector [18]. Concerns were raised about the appropriateness of catch shares for the commercial sector when the recreational sector was not bound to its share of the TAC. Another issue was how to deal with commercial catch shares being purchased by recreational fishermen. In an effort to increase its share of the TAC, it was possible that the recreational sector could "buy up" catch shares. The Hawai'i bottomfish fishery would appear to share a lot of similar characteristics to fisheries that have used equal share or vessel-based rules, although there is fairly strong opposition to any form of catch shares management in this fishery.

One obvious weakness of the current study is that we have not included a category for allocations to indigenous peoples. This data proved much more difficult to track down and verify but it has been a feature of allocation in Alaska, parts of Canada and New Zealand. For example, 20\% of every new ITQ program in New Zealand is allocated to the Māori community. This type of allocation would obviously be very important for Hawai'i (especially for the culturally important bottomfish fishery) and deserves further study. Nevertheless, it is hoped that the breadth of experiences represented in the current version of the database will make an intellectual contribution to discussions about catch share allocation in Hawai'i and across the world.

\section{Acknowledgements}

The author wishes to thank Andrew Salazar for valuable research assistance. The Sustainable Fisheries Division, Pacific Islands Regional Office, National Marine Fisheries Service provided support for this project under Award No. AB133F09SE4857 "Strategic Planning for Administering Catch Share Programs" from the National Oceanic and Atmospheric Administration (NOAA). The views expressed herein are those of the 
author and do not necessarily reflect the views of NOAA or any of its sub-agencies. 


\section{References}

[1] J.K. Abbott, B. Garber-Yonts, and J.E. Wilen. Employment and Remuneration Effects of IFQs in the Bering Sea/Aleutian Islands Crab Fisheries. Marine Resource Economics, 25(4):333-354, 2010.

[2] C.M. Anderson and D.S. Holland. Auctions for initial sale of annual catch entitlement. Land Economics, 82(3):333-352, 2006.

[3] T.L. Anderson, R. Arnason, and G.D. Libecap. Efficiency Advantages of Grandfathering in Rights-Based Fisheries Management. Annual Review of Resource Economics, 3:159-179, 2011.

[4] E. Anferova, M. Vetemaa, and R. Hannesson. Fish quota auctions in the Russian Far East: a failed experiment. Marine Policy, 29(1):47-56, 2005.

[5] R. Arnason. A review of international experiences with ITQs. Annex to Future Options for UK Fishing Management, Report to the Department for the Environment, Food and Rural Affairs, CEMARE, University of Portsmouth, UK, 2002.

[6] T.A. Branch. How do individual transferable quotas affect marine ecosystems? Fish and Fisheries, 10(1):39-57, 2009.

[7] D.W. Bromley. Abdicating responsibility: the deceits of fisheries policy. Fisheries, 34(6):280-290, 2009.

[8] T.N. Cason. What Can Laboratory Experiments Teach Us About Emissions Permit Market Design? Agricultural and Resource Economics Review, 39(2):151-161, 2010.

[9] C. Chu. Thirty years later: the global growth of itqs and their influence on stock status in marine fisheries. Fish and Fisheries, 10(2):217-230, 2009.

[10] C. Costello, S.D. Gaines, and J. Lynham. Can catch shares prevent fisheries collapse? Science, 321(5896):1678, 2008.

[11] C. Costello, J. Lynham, S.E. Lester, and S.D. Gaines. Economic incentives and global fisheries sustainability. Annu. Rev. Resour. Econ., 2(1):299-318, 2010.

[12] WP Davidse. The effects of transferable property rights on the fleet capacity and ownership of harvesting rights in the dutch demersal north sea fisheries. In R. Shotton, editor, Case studies on the allocation of transferable quota rights in fisheries. FAO Fisheries Technical Paper 411. Rome: FAO, 2001.

[13] T.E. Essington. Ecological indicators display reduced variation in North American catch share fisheries. Proceedings of the National Academy of Sciences, 107(2):754, 2010. 
[14] T.E. Essington, M.C. Melnychuk, T.A. Branch, S.S. Heppell, O.P. Jensen, J.S. Link, S.J.D. Martell, A.M. Parma, J.G. Pope, and A.D.M. Smith. Catch shares, fisheries and ecological stewardship: a comparative analysis of resource responses to a rights-based policy instrument. Conservation Letters, 2012.

[15] J.R. Gauvin, J.M. Ward, and E.E. Burgess. Description and evaluation of the wreckfish (polyprion americanus) fishery under individual transferable quotas. Marine Resource Economics, 9(2):99-118, 1994.

[16] G. Heal and W. Schlenker. Sustainable fisheries. Nature, 455(7216):1044-1045, 2008.

[17] R. Hilborn. Managing fisheries is managing people: what has been learned? Fish and Fisheries, $8(4): 285-296,2007$.

[18] WR Keithly. Initial allocation of ITQs in the Gulf of Mexico red snapper fishery. In R. Shotton, editor, Case studies on the allocation of transferable quota rights in fisheries. FAO Fisheries Technical Paper 411. Rome: FAO, 2001.

[19] J.O. Ledyard. Market design for fishery ifq programs. California Institute of Technology, Social Science Working Paper No. 1301, 2009.

[20] J. Lynham, C. Costello, SD Gaines, Grafton RQ, and Prince J. Diverse fisheries require diverse solutions: response. Science, 323:338-9, 2009.

[21] M.C. Melnychuk, T.E. Essington, T.A. Branch, S.S. Heppell, O.P. Jensen, J.S. Link, S.J.D. Martell, A.M. Parma, J.G. Pope, and A.D.M. Smith. Can catch share fisheries better track management targets? Fish and Fisheries, 2011.

[22] J.P. Montero, J.M. Sanchez, and R. Katz. A market-based environmental policy experiment in Chile. Journal of Law and Economics, 45(1):267-287, 2002.

[23] G.R. Morgan. Initial allocation of harvesting rights in the fisheries of south australia. In R. Shotton, editor, Case studies on the allocation of transferable quota rights in fisheries. FAO Fisheries Technical Paper 411. Rome: FAO, 2001.

[24] J. Peña-Torres. The political economy of fishing regulation: the case of Chile. Marine Resource Economics, 12:253-280, 1997. 
[25] B. Runolfsson and R. Arnason. Initial allocation of itqs in the icelandic fisheries. In R. Shotton, editor, Case studies on the allocation of transferable quota rights in fisheries. FAO Fisheries Technical Paper 411. Rome: FAO, 2001.

[26] M.P. Sissenwine and P.M. Mace. ITQs in New Zealand: The era of fixed quota in perpetuity. Fishery Bulletin, 90(1):147-160, 1992.

[27] W. Smit. Dutch demersal north sea fisheries: initial allocation of flatfish itqs. In R. Shotton, editor, Case studies on the allocation of transferable quota rights in fisheries. FAO Fisheries Technical Paper 411. Rome: FAO, 2001.

[28] M.D. Smith, J. Lynham, J.N. Sanchirico, and J.A. Wilson. Political economy of marine reserves: Understanding the role of opportunity costs. Proceedings of the National Academy of Sciences, 107(43):18300$18305,2010$.

[29] C. Sporer. Initial allocation of transferable fishing quotas in canada's pacific marine fisheries. In R. Shotton, editor, Case studies on the allocation of transferable quota rights in fisheries. FAO Fisheries Technical Paper 411. Rome: FAO, 2001.

[30] R.N. Stavins. Transaction costs and tradeable permits. Journal of Environmental Economics and Management, 29(2):133-148, 1995.

[31] M. Turner and Q. Weninger. Meetings with costly participation: An empirical analysis. Review of Economic Studies, 72(1):247-268, 2005.

[32] B. Turris. A comparison of british columbia's itq fisheries for groundfish trawl and sablefish: Similar results from programmes with differing objectives, designs and processes. In R. Shotton, editor, Use of Property Rights in Fisheries Management, pages pp 254-261. FAO Fisheries Technical Paper 404/1, 2000.

[33] M. Vetemaa, M. Eero, and R. Hannesson. The Estonian fisheries: from the Soviet system to ITQs and quota auctions. Marine Policy, 26(2):95-102, 2002. 